\title{
The influence of network environment on College Students' spoken English
}

\author{
HongHong \\ Nanchang Institute of Science \& Technology, Nanchang 330108,China
}

Key words: network environment; spoken English; Internet chat room; language environment

\begin{abstract}
In College English teaching, oral English is always a weak link. With the development and the widespread use of the Internet, the Internet provides a new opportunity for college students' oral English teaching, it can improve realistic oral English environment for students, can increase the expression of college students effective oral English ability. The use of network tools such as Internet chat rooms, can create a virtual language environment for students, and it is helpful to improve college students' oral English proficiency.
\end{abstract}

\section{Introduction}

With China's accession to the world trade organization, English learning has become more and more important, which is also a new challenge for college students' English ability, especially oral English ability. In the process of English learning, oral communication ability is a very important aspect, but there is a common phenomenon in college students in china. This is mainly because teachers mainly focus on fostering the students' ability of reading and writing ability in the process of English Teaching in China's traditional, and do not pay attention to the cultivation of students' oral English ability, so many college students can just write in English but do not speak english. In order to change this situation, it is necessary for the teachers to put forward the corresponding measures according to the problems existing in the current oral English Teaching in Colleges and universities, so as to effectively improve the effect of oral English teaching.

\section{The problems in oral Colleges English Teaching}

Oral English plays an important role in College English teaching, but also a difficult point in College English teaching. How to better carry out the teaching of spoken English is also the focus of attention of many college teachers, first we should analyze the existing problems in college oral English teaching:

(1) Lack of context for oral English learning

At present, many college students learn oral English through the short time of classroom teaching, there is no longer independent of oral English practice after class, which is very detrimental to the study of spoken English. Learning spoken English is a process of accumulation, it is not enough just to learn and practice oral English by classroom time.

(2) Students do not pay enough attention to oral English, and lack of enthusiasm

The current college English final exam, the scores proportion of oral English is very small, resulting in a lot of college students think they can do and look, do not usually pay attention to oral practice, and just taking a little practice my English spoken language for the exam before the exam, and having no enthusiasm to learn spoken English in the free time.

(3)Lack of vitality in oral English class 
In traditional English teaching, teachers can only repeated explanation, let the students to practice using the language and patterns of machinery, the oral English teaching classroom becomes very dull and boring, no vitality, students can easily produce boredom in spoken English.

\section{The network environment has brought new opportunities for college oral English Teaching}

The network environment provide oral practice environment for college students. Along with the Internet technology continues to mature, high-quality cyber source constantly being used by people, and it also provides a good environment for students to practice oral English, more convenient for college oral English teaching. For example, many students can learn English place in Sina and UC site, students can be devoted to the pronunciation and intonation learning using Sina and UC website, can also be oral and listening training, which can also in English above and foreign exchanges, a better understanding of foreign culture and history, living habits and other local customs and practices and, it can effectively improve the students' communicative competence.

The network environment provide flexible learning methods for college students. In the network environment, the education mechanism can only use of computer networks , not be limited by time, space and region, educational mechanisms can be extended to every corner of the world. Under this kind of education mechanism, the student may carry on the free study at any place, any time, through the network, this can arouse student's enthusiasm and the initiative. As we all know, it can not be completed in a short period of time that learning spoken English, students are needed to spend a lot of time to practice listening and speaking, short classroom time learning is not enough. With the network education mechanism, students will not have to rely solely on the teacher to learn spoken English.

The network environment can stimulate students' interest in learning spoken English. Einstein once said: "interest is the best teacher", a strong interest in learning, can stimulate students' enthusiasm for learning, and can effectively develop students' communicative competence. Oral English teaching is not only to impact language knowledge to students, but also to enable students to use in life and work, which requires teachers to combine the content of teaching materials and real life together, to create a good environment of network language in the classroom, so that students can chat in English, watch English movies, English television and other forms of learning English by using the network, resulting in oral English learning enthusiasm. At the beginning of learning English, students always worry about their pronunciation and intonation is not standard, and be afraid of using English to communicate with others, this is one of the important psychological factors influencing college students' oral English learning obstacles in our country, which is not the language exchange opportunities are not reasonable use, students' oral English ability don't get sufficient exercise. In the network environment, students are free to express their views, do not care too much about their grammatical forms of right and wrong, can be very good for students to actively express their ideas in English. At the same time, in the network environment, students can also control their own communication time and speed, thereby anxiety can be reduced when the students can not keep up with other people's dialogue, which is helpful to improve the confidence of students.

\section{Measures of Cultivating College Students' oral English ability in the network environment}

Use the network environment to organize spoken English training .In the network environment, we should make full use of the characteristics of collaborative learning and personalized learning to carry out college students' oral English training activities. Teachers can let the students in groups to 
discuss the topic in English, their own interests, college life, personal knowledge, etc. can be discussed in the classroom, and then each group sent a representative to the podium to report on their own opinions and exchange content. In the class, the teacher can guide the students to browse the Internet on their own interested in English content, and through QQ, WeChat and other network communication tools to communicate their experience. Teachers can also arrange students to watch some English audio materials before class, then the teacher in the classroom to let students play a role to read audio material content, which can make students feel involved, deepen the impression of the students. Teachers can also download some online listening materials, such as online news, so that students discuss and ask each other. Teachers can also make good use of online games for spoken English training, teachers can design a variety of listening and speaking activities according to the game, so that students can learn English in the process of entertainment. A good language environment, can not only stimulate students' interest in practicing oral English, but also improve students' oral expression ability.

Using Internet chat room to teach spoken English. With the development of network communication and network course, people pay more and more attention to the voice chat room as an English teaching method. Traditional oral English teaching is monotonous and boring. In the network environment, teachers can use the virtual technology to construct a language learning environment, in which students can communicate with others in different situations. In the voice chat room, you can use the form of debate to train students' oral expression ability, cultivate students' language ability and language communication ability. The combination of traditional teaching and voice chat has become an important part of network teaching. The network chat room can give students to create a relaxed and pleasant learning atmosphere, in a chat room, students can be used anonymously for free play, can also according to their own interests, spoken English into different chat rooms to practice, but also requires the teacher to guide the direction of the chat, to express their unique insights to improve the students' learning enthusiasm. At the same time, teachers should be based on the teaching content and the actual situation to specify the theme of the chat, to guide students around the theme of a positive discussion.

Create a learning platform for spoken English. Teachers can make full use of campus network to create platform for spoken English learning, so that students can learn English in their spare time,, students can learn English phonogram in the network, English pronunciation, listening to the American film soundtrack with English songs and English radio, listening to the process. Students can gradually accumulate knowledge of English, English vocabulary and sentence, so that students' oral English level can also be significantly improved.

\section{Conclusion}

In short, in the network environment, we should fully utilize the network information technology to create a good environment for students to practice pronunciation, so that students can contact English widely, cultivate students better oral English ability, then students can live and work in the fluent in English communication. To learn English is not a day. It also requires students not only to the reasonable use of classroom learning time, but also in the course of learning autonomy. The reform of oral English teaching mode under the network environment is of great significance to improve the level of oral English Teaching in Colleges and universities in china. 


\section{References}

[1] Li Xiuwen. Investigation and Study on the oral English ability of college graduates in Changchun [J]. Ability and Wisdom, 34, (2015) , p.189

[2] Liu Xiaolan. Study on the effect of Interactive English Teaching in Higher Vocational Colleges on students' oral competence based on interaction hypothesis [D]. Ocean University of China, (2014)

[3] Li Muzi. The application of situational approach to oral English Teaching in Higher Vocational Education [D]. Liaoning Normal University, (2014)

[4] Sui Xiaobing. Optimization of College English classroom teaching under the network environment [D]. Shanghai International Studies University, (2013)

[5] Fang Jiahui. Problems and Countermeasures of college oral English teaching to discuss [J]. Journal of Chifeng University(Natural Science Edition), No. 13, (2013) , p.255-256.

[6] Li Xinli. The study of Higher Vocational English teaching model based on network platform [J]. English Square (Academic research), No.11, (2012), p.55-56.

[7] Li Meng. On the cultivation of middle school students' oral English ability under the new curriculum [J]. Tourism Overview, No.10, (2012), p.163

[8] Ding Ting. The cultivation of College Students' spoken English ability under the network environment [J]. Industry \& Science Tribune, 17, (2012), p.180-181.

[9] Che Tongbo. The effect of group activities on the cultivation of students' oral communicative competence in College English teaching [D]. Northeast Normal University, (2002)

[10] Zheng Peiyun. A study on College English oral English teaching based on online real time communication [D]. Shanghai International Studies University, (2011)

[11] Zhang Shanjun. The study of College English Interactive Teaching Model under the environment of information technology [D]. Shanghai International Studies University, (2011)

[12] Sun Xiaohong, Ren Lijun. How to cultivate students' ability of oral English Teaching in College [J]. Legend. Biographies (Theory), No.08, (2010), p.64,68.

[13] Shi Hongshi, Zhang Tao, Zhu Hanchang, Zhao Ping. The practice and research of oral English training of College English PGC in the multimedia network environment [J]. Journal of Higher Correspondence Education (Philosophy and Social Sciences Edition), (2008), p.53-56,65.

[14] Sun Lin. Study on the problems and Countermeasures in the development of College English oral communicative competence [D]. Hunan Normal University, (2007)

[15] Pan Fei. Exploration of College English teaching mode under the environment of multimedia and network technology [D]. Shanghai International Studies University, (2007)

[16] Qi Ying. Exploration of college oral English teaching mode under the network environment [J]. Heilongjiang Education (Higher Education Research \& Appraisal), No.06, (2006), p.64-65.

[17] Wen Jing. A preliminary study on the cultivation of College Students' autonomous learning awareness to improve their oral English ability [D]. Guizhou University, (2006) 
[18] Wu Jing. Study on the teaching mode of English for graduate students in multimedia and network environment [J]. Journal of Liupanshui Normal College, No.02 , (2005), p.40-42,49. 